\title{
BETON BERMUTU DAN RAMAH LINGKUNGAN DENGAN MEMANFAATKAN LIMBAH TONGKOL JAGUNG (Penelitian Laboratorium)
}

\author{
Johan Oberlyn Simanjuntak $^{1}$, Tiurma Elita Saragi ${ }^{2}$, Belinauli Teknika Lumbangaol ${ }^{3}$ \\ Fakultas Teknik Sipil Universitas HKBP Nommensen \\ Email: Oberlyn.simanjuntak@yahoo.co.id,Saragih_27@yahoo.com
}

\begin{abstract}
The need for housing is more higher along with the times and this is also a factor to increasing for concrete needed for building development. The more concrete that is produced, the more cement is needed for construction.Concrete is a composite material (mixture) of several materials, the main ingredient which consists of a mixture of cement, fine aggregate, coarse aggregate, water and or without other additives with a certain ratio.

Utilization of waste carried out in this study is to utilize corn cobs waste which is commonly found in the outskirts of the city of Medan. By utilizing this waste, it is hoped that it can reduce the accumulation of corn agricultural waste and also increase public insight about how to treat corn cobs waste into other forms. In this study, a concrete trial was carried out by adding corn cobs ash waste to concrete which aims to find out whether corn cobs ash can increase the compressive strength of concrete with variations in the percentage of the mixture of $0 \%, 3 \%, 6 \%$, and $9 \%$ of the cement weight.

The compressive strength value of normal concrete $(25.45 \mathrm{MPa})$, while with the substitution of corn cob ash $3 \%(21.96 \mathrm{MPa}), 6 \%(18.56 \mathrm{MPa})$, and $9 \%(16.45 \mathrm{MPa})$. So it can be concluded that the resulting compressive strength exceeds the planned compressive strength and the optimum substitution value of corn cobs varian is at the $3 \%$ variant, namely $21.96 \mathrm{MPa}$.
\end{abstract}

Keywords: Concrete, Environmentally Friendly, Cement, Fine Aggregate, Compressive Strength.

\section{PENDAHULUAN}

\subsection{Latar Belakang Masalah}

Beton ramah lingkungan yang menggunakan lebih sedikit energy dalam produksinya dan menghasilkan lebih sedikit $\mathrm{CO}_{2}$ daripada beton normal disebut beton hijau (green concrete) atau yang lebih dikenal dengan nama beton ramah lingkungan. Tujuan pengembangan beton ramah lingkungan ini adalah untuk pembangunan berkelanjutan tanpa merusak sumber daya alam. Bahan utama dalam beton ramah lingkungan adalah semen yang terdiri dari batu kapur. Selama pembuatan semen, bahan-bahannya dipanaskan sampai sekitar $800^{\circ} \mathrm{C}$ hingga $10000^{\circ} \mathrm{C}$. Selama proses ini, karbondioksida dilepaskan. Sekitar $1 \mathrm{~kg}$ lemparan beton sekitar 900 gms $\mathrm{CO}_{2}$ keatmosfir. Karena itu, beton ramah lingkungan menjadi eksistensi untuk mengurangi emisi $\mathrm{CO}_{2}$.

Campuran beton untuk beton ramah lingkungan sama dengan beton konvensional, namun kebutuhan material pendukung harus dicampur sedemikian rupa sehingga menempati nilai minimum atau void minimum dalambeton. Material beton ini dipakai dari bahan yang dipergunakan kembali, tergantung dari tujuan penggunaan beton ramah lingkungan ini. 
Keunggulan beton ramah lingkungan :

1. Desain campuran yang dioptimalkan berarti penanganan yang lebihmudah, konsistensi yang lebihbaik, dan penyelesaian yang lebih mudah.

2. Pengurangan penyusutan dan creep.

3. Beton ramah lingkungan menggunakan material lokal dan daur ulang.

4. Panas hidrasi secara teknis lebih rendah dari pada beton tradisional.

5. Hal ini menghasilkan kenaikan suhu yang lebih rendah dalam menuangkan beton massa yang merupakan keunggulan nyata dari beton ramah lingkungan. Kerugian beton ramah lingkungan :

1. Penyerapan air tinggi.

2. Struktur yang dibangun dengan beton ramah lingkungan memiliki waktu layan kurang dari struktur yang dibangun dengan beton konvensional.

3. Kekuatan tegang beton ramah lingkungan kurang dari beton konvensional..

\subsection{Rumusan Masalah}

1. Bagaimana pengaruh kuat tekan beton dengan memanfaatkan material organik abu tongkol jagung pada campuran beton?

2. Apakah dengan penambahan abu tongkol jagung sebagai bahan tambah dapat menambah kuat tekan beton?

3. Apakah limbah abu tongkol jagung layak digunakan untuk menambah kekuatan beton?

4. Bagaimana persentase abu tongkol jagung dan semen yang paling optimum ?

\subsection{Tujuan Penelitian}

Penelitian ini bertujuan untuk mengetahui kuat tekan beton normal dengan beton yang menggunakan abu tongkol jagung sebagai bahantambah.

\subsection{Manfaat Penelitian}

Manfaat yang diharapkan dari penilitian ini adalah sebagai berikut ini.

1. Untuk meningkatkan kualitas beton, sehingga diharapkan dapat merekomendasikan penggunaan abu tongkol jagung sebagai peningkatan mutu beton.

2. Menekan biaya pembuatan beton karena menggunakan bahan limbah yang tidak terpakai.

\subsection{Batasan Masalah}

Batasan masalah dari penelitian ini diambil sebagai berikut ini. 
1. Semen yang digunakan tipe 1 merk Semen Padang.

2. Tongkol jagung diambil dari daerah Tembung, Medan.

3. Pasir diambil dari daerah Binjai.

4. Agregat kasar yang digunakan berasal dari daerah Binjai.

5. Air berasal dari Laboratorium Konstruksi dan Mekanika Bahan Universitas HKBP Nommensen Medan.

6. Benda uji berbentuk silinder dengan ukuran diameter $15 \mathrm{~cm}$ dan tinggi $30 \mathrm{~cm}$.

7. Pengujian sampel : 7, 14, 21, 28 hari.

8. Persentase tongkol jagung : $0 \%, 3 \%, 6 \%, 9 \%$.

9. Benda uji yang dihasilkan 48 buah.

10. Mutu beton ( f'c ) $25 \mathrm{Mpa}$.

11. Tongkol jagung dibakar sampai menjadi abu.

12. Abu tongkol jagung lolos saringan No.100 dan tertahan di No.200

\section{TINJAUAN PUSTAKA}

\subsection{Pengertian Umum}

Beton merupakan suatu bahan komposit (campuran) dari beberapa material, yang bahan utamanya terdiri dari campuran antara semen, agregat halus, agregat kasar, air dan atau tanpa bahan tambah lain dengan perbandingan tertentu. Karena beton merupakan komposit, maka kualitas beton sangat tergantung dari kualitas masingmasing material pembentuk. Agar dihasilkan kuat tekan beton yang sesuai dengan rencana diperlukan mix design untuk menentukan jumlah masing-masing bahan susun yang dibutuhkan.

\subsection{Bahan-bahan Penyusun Beton}

\subsubsection{Semen Portland}

Komponen semen portland terdiri dari :
a. Trikalsium Silikat $\left(\mathrm{C}_{3} \mathrm{~S}\right)$
b. Dikalsium Silikat $\left(\mathrm{C}_{2} \mathrm{~S}\right)$
c. Trikalsium Aluminat $(\mathrm{C}, \mathrm{A})$
d. Tetrakalsium Aluminoferit $\left(\mathrm{C}_{4} \mathrm{AF}\right)$

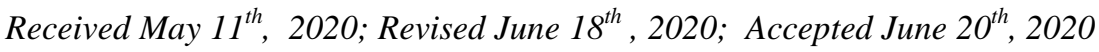


Tabel 2.1. Komposisi Oksida Semen Portland

\begin{tabular}{|c|c|}
\hline Oksida & Komposisi (\%) \\
\hline $\mathrm{CaO}$ & $60-65$ \\
\hline $\mathrm{SiO}_{2}$ & $17-25$ \\
\hline $\mathrm{Al}_{2} \mathrm{O}_{3}$ & $3-8$ \\
\hline $\mathrm{Fe}_{2} \mathrm{O}_{3}$ & $0,5-6$ \\
\hline $\mathrm{MgO}$ & $0,5-4$ \\
\hline $\mathrm{SO}_{3}$ & $1-2$ \\
\hline $\mathrm{K}_{2} \mathrm{O}, \mathrm{Na}_{2} \mathrm{O}$ & $0,5-1$ \\
\hline
\end{tabular}

Sumber : Kardiyono Tjokrodimuljo, 2007

\subsubsection{Air}

Dalam pembuatan beton, air merupakan salah satu faktor penting, karena air dapat bereaksi dengan semen, yang akan menjadi pasta pengikat agregat. Air juga berpengaruh terhadap kuat tekan beton, karena kelebihan air akan menyebabkan penurunan pada kekuatan beton itu sendiri.

\subsubsection{Agregat}

Agregat adalah butiran mineral yang merupakan hasil disintegrasi alami batubatuan atau juga berupa hasil mesin pemecah batu dengan memecah batu alami. Agregat merupakan salah satu bahan pengisi pada beton, namun demikian peranan agregat pada beton sangatlah penting. Kandungan agregat dalam beton kira-kira mencapai $70 \%$ - 75\% dari volume beton. Agregat dibedakan menjadi dua macam yaitu agregat halus ( pasir ) dan agregat kasar (kerikil) yang didapat secara alami atau buatan.

Tabel 2.2. Gradasi Pasir

\begin{tabular}{|c|c|c|c|c|}
\hline \multirow{2}{*}{$\begin{array}{c}\text { Lubang } \\
\text { ayakan (mm) }\end{array}$} & \multicolumn{4}{|c|}{ Persen bahan butiran yang lewat ayakan } \\
\cline { 2 - 5 } & Daerah I & $\begin{array}{c}\text { Daerah II } \\
\text { Pasir agak } \\
\text { pasir kasar }\end{array}$ & $\begin{array}{c}\text { Daerah III } \\
\text { Pasir agak } \\
\text { halus }\end{array}$ & $\begin{array}{c}\text { Daerah IV } \\
\text { Pasir halus }\end{array}$ \\
\hline 10 & 100 & 100 & 100 & 100 \\
\hline
\end{tabular}

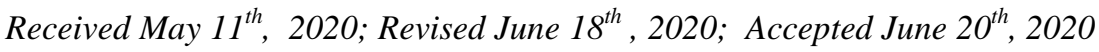




\begin{tabular}{|c|c|c|c|c|}
\hline 4,8 & $90-100$ & $90-100$ & $90-100$ & $95-100$ \\
\hline 2,4 & $60-95$ & $75-100$ & $85-100$ & $95-100$ \\
\hline 1,2 & $30-70$ & $55-90$ & $75-100$ & $90-100$ \\
\hline 0,6 & $15-34$ & $35-59$ & $60-79$ & $90-100$ \\
\hline 0,3 & $5-20$ & $8-30$ & $12-40$ & $15-50$ \\
\hline 0,15 & $0-10$ & $0-10$ & $0-10$ & $0-15$ \\
\hline
\end{tabular}

Sumber : Kardiyono Tjokrodimulyo, 2007

Tabel 2.3.Gradasi Kerikil

\begin{tabular}{|c|c|c|}
\hline \multirow{2}{*}{ Lubang ayakan $(\mathrm{mm})$} & \multicolumn{2}{|c|}{ Persen bahan butiran yang lewat ayakan } \\
\cline { 2 - 3 } & \multicolumn{2}{|c|}{ Berat butir maksimum } \\
\cline { 2 - 3 } & $40 \mathrm{~mm}$ & $20 \mathrm{~mm}$ \\
\hline 40 & $95-100$ & 100 \\
\hline 20 & $30-70$ & $95-100$ \\
\hline 10 & $10-35$ & $25-55$ \\
\hline 4,8 & $0-5$ & $0-10$ \\
\hline
\end{tabular}

Sumber : Kardiyono Tjokrodimulyo, 2007

\subsubsection{Tongkol Jagung}

Tanaman jagung merupakan salah satu tanaman pangan penghasil karbohidrat yang terpenting di dunia, selain gandum dan juga padi. Untuk hal ini di beberapa negara seperti di wilayah Amerika Tengah dan Selatan, bulir jagung menjadi makanan pokok. Dan begitu juga di beberapa wilayah Afrika dan Indonesia sendiri. 


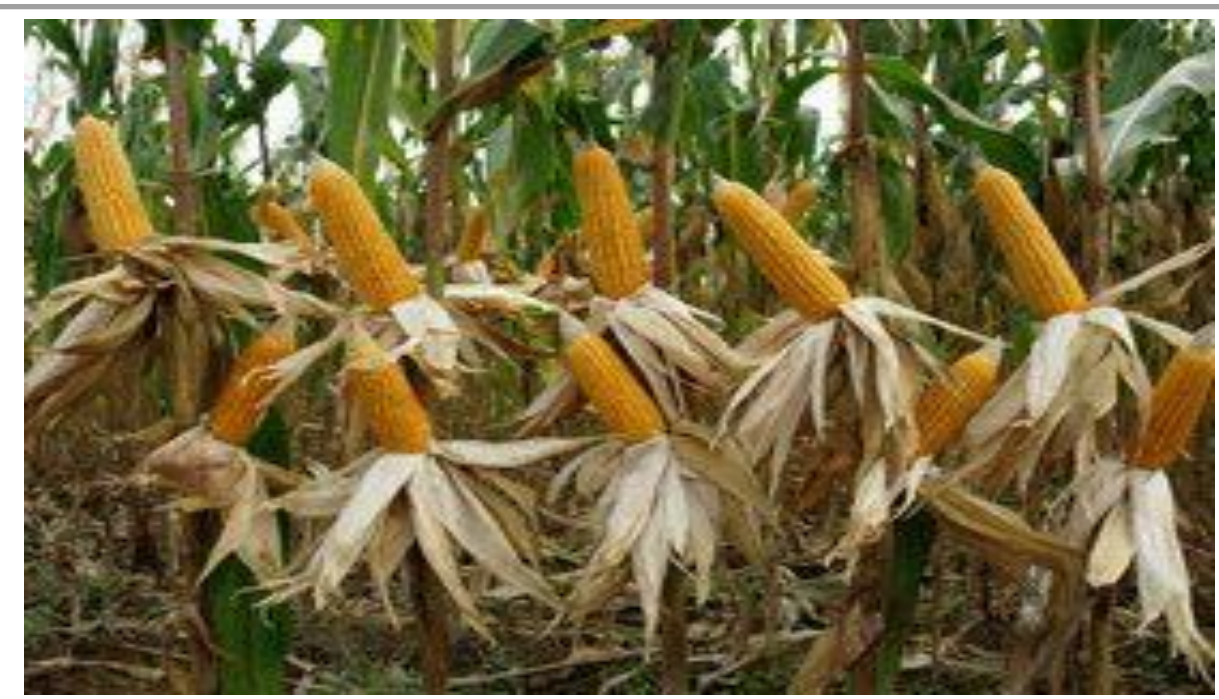

Gambar 2.1. Tanaman Jagung

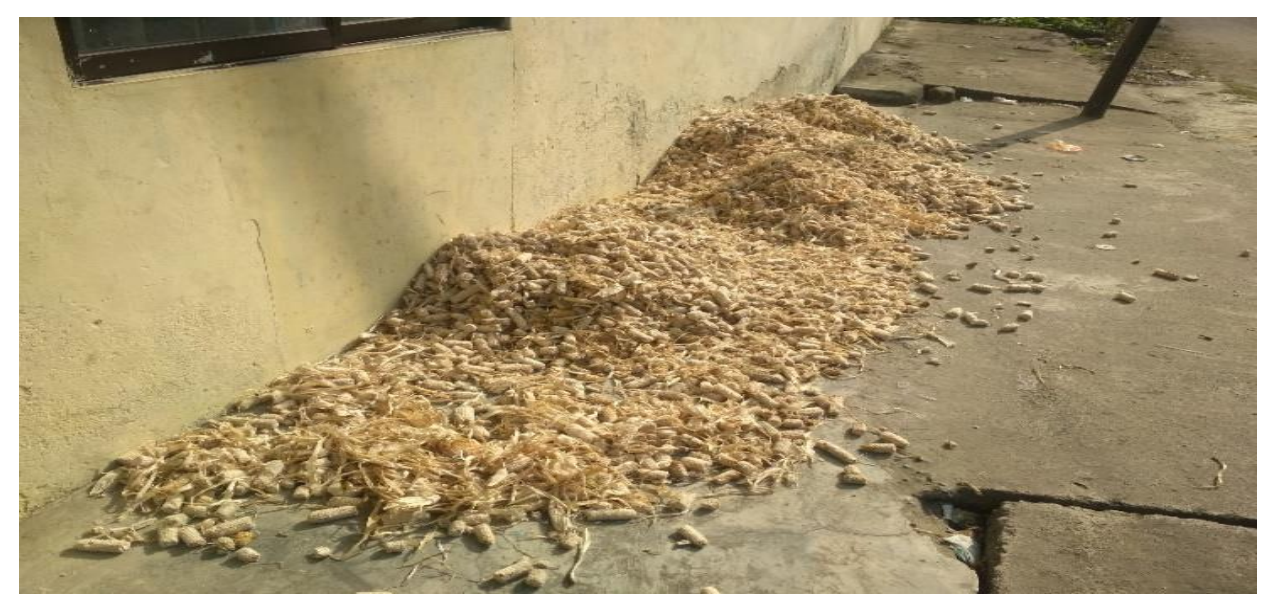

Tabel 2.4. Hasil Uji Unsur Kimia Abu Tongkol Jagung

\begin{tabular}{|c|c|}
\hline KOMPOSISI & HASIL UJI \\
\hline $\mathrm{Si}$ & $8,75 \%$ \\
\hline $\mathrm{P}$ & $2,4 \%$ \\
\hline $\mathrm{S}$ & $0,4 \%$ \\
\hline $\mathrm{K}$ & $81,2 \%$ \\
\hline $\mathrm{Ti}$ & $0,07 \%$ \\
\hline $\mathrm{Mn}$ & $0,12 \%$ \\
\hline $\mathrm{Fe}$ & $1,05 \%$ \\
\hline $\mathrm{Cu}$ & $0,16 \%$ \\
\hline $\mathrm{Zn}$ & $0,16 \%$ \\
\hline
\end{tabular}

Received May 11 ${ }^{\text {th }}$, 2020; Revised June 18 $8^{\text {th }}$,2020; Accepted June $20^{\text {th }}, 2020$ 


\begin{tabular}{|c|c|}
\hline $\mathrm{Br}$ & $1,12 \%$ \\
\hline $\mathrm{Rb}$ & $0,30 \%$ \\
\hline $\mathrm{Y}$ & $1,1 \%$ \\
\hline $\mathrm{Mo}$ & $0,06 \%$ \\
\hline $\mathrm{Ba}$ & $3,0 \%$ \\
\hline $\mathrm{Eu}$ & $0,2 \%$ \\
\hline
\end{tabular}

Sumber : Penelitian Abu Tongkol Jagung dari Desa Gedog Wetan, Kec. Turen, Kab. Malang

\subsection{Bahan Tambah}

Bahan tambah adalah bahan selain unsur pokok beton (air, semen, dan agregat) yang ditambahkan pada adukan beton. Bahan tambah ini biasanya diberikan dalam jumlah yang relatif sedikit, dan agar tidak berlebihan yang justru akan dapat memperburuk sifat beton. Sifat-sifat beton yang diperbaiki itu antara lain kecepatan hidrasi (waktu pengikatan), kemudahan pengerjaan, dan kekedapan terhadap air. Menurut SK SNI S-18-1990-03 (Spesifikasi Bahan Tambahan Untuk Beton, 1990)

\subsection{Slump}

Slump merupakan salah satu pengetesan sederhana untuk mengetahui workability beton segar sebelum diterima dan diaplikasikan dalam pekerjaan pengecoran.

\subsection{Faktor Air Semen}

Faktor air semen (fas) adalah perbandingan berat air dan berat semen yang digunakan dalam adukan beton. Umumnya nilai faktor air semen minimum untuk beton normal sekitar 0,4 dan maksimum 0,65. (Tri Mulyono, 2003).

\subsection{Kuat Tekan Beton}

Nilai kuat tekan beton dinyatakan dalam satuan Mpa atau $\mathrm{kg} / \mathrm{cm}^{2}$.

$$
\begin{array}{r}
f^{\prime} c i=\frac{P}{A} x \frac{1}{f u} \ldots \ldots \ldots \ldots \ldots . . . . . . . \\
f^{\prime} c r=\frac{\sum_{i=1}^{n} f^{\prime} c i}{n} \ldots \ldots . . \\
S d=\sqrt{\frac{\left(f^{\prime} c i-f^{\prime} c r\right)^{2}}{(n-1)}} \ldots . . \\
f^{\prime} c=f^{\prime} c r-1,64 s d
\end{array}
$$


Keterangan :

$\mathrm{P}=$ Beban kuattekan $(\mathrm{N})$

A $\quad=$ Luas penampang

$\mathrm{fu} \quad=$ faktorumur

$\mathrm{f}^{\prime} \mathrm{ci}=$ Kuattekanbeton pada keadaanawal

f'cr = Kuattekan rata-rata $(\mathrm{MPa})$

f'c = Kuattekan $(\mathrm{MPa})$

\section{METODE PENELITIAN}

\subsection{Tempat Penelitian}

Metode penelitian yang digunakan pada penelitian ini adalah metode eksperimen. Metode eksperimen pada penelitian ini dilakukan dengan cara membandingkan beton normal f'c = 25 Mpasebagai kontrol dengan beton yang akan dieksperimen. Beton tersebut akan diuji dengan pengujian kuat tekan beton. Dari hasil pengamatan penelitian terhadap beton yang dieksperimenkan, diharapkan dapat mengetahui pengaruh penambahan abu tongkol jagung terhadap kuat tekan beton.

\subsection{Variabel dan Parameter}

Variabel adalah atribut dari sekelompok objek yang mempunyai variasi antara satu objek dengan objek lainnya dalam kelompok tersebut sebagai mana yang dikemukakan oleh Sugiyono (2002:2).

Variabel dalam penelitian ini campuran beton dengan mensubsitusi sebagian semen dengan abu tongkol jagung. Pada penelitian ini jumlah sampel ditentukan masing-masing 3 sampel tiap varian yang ditetapkan.

Tabel 3.1. Jumlah Sampel Benda Uji

\begin{tabular}{|c|c|c|c|c|c|}
\hline \multirow{2}{*}{ KELOMPOK } & \multicolumn{4}{|c|}{$\begin{array}{l}\text { JUMLAH PENGUJIAN KUAT TEKAN PADA } \\
\text { UMUR }\end{array}$} & \multirow{2}{*}{$\begin{array}{l}\text { JUMLAH } \\
\text { BENDA UJI }\end{array}$} \\
\hline & 7hari & 14hari & 21hari & 28hari & \\
\hline Beton Normal & 3 & 3 & 3 & 3 & 12 \\
\hline \multicolumn{6}{|l|}{ Beton Eksperimen : } \\
\hline $3 \%$ ATJ & 3 & 3 & 3 & 3 & 12 \\
\hline $6 \% \mathrm{ATJ}$ & 3 & 3 & 3 & 3 & 12 \\
\hline $9 \%$ ATJ & 3 & 3 & 3 & 3 & 12 \\
\hline
\end{tabular}

Received May 11 $1^{\text {th }}$, 2020; Revised June 18 ${ }^{\text {th }}$, 2020; Accepted June $20^{\text {th }}$, 2020 


\begin{tabular}{|l|l|l|l|l|l|}
\hline JUMLAH & 12 & 12 & 12 & 12 & 48 \\
\hline
\end{tabular}

\subsection{Alur Penelitian :}

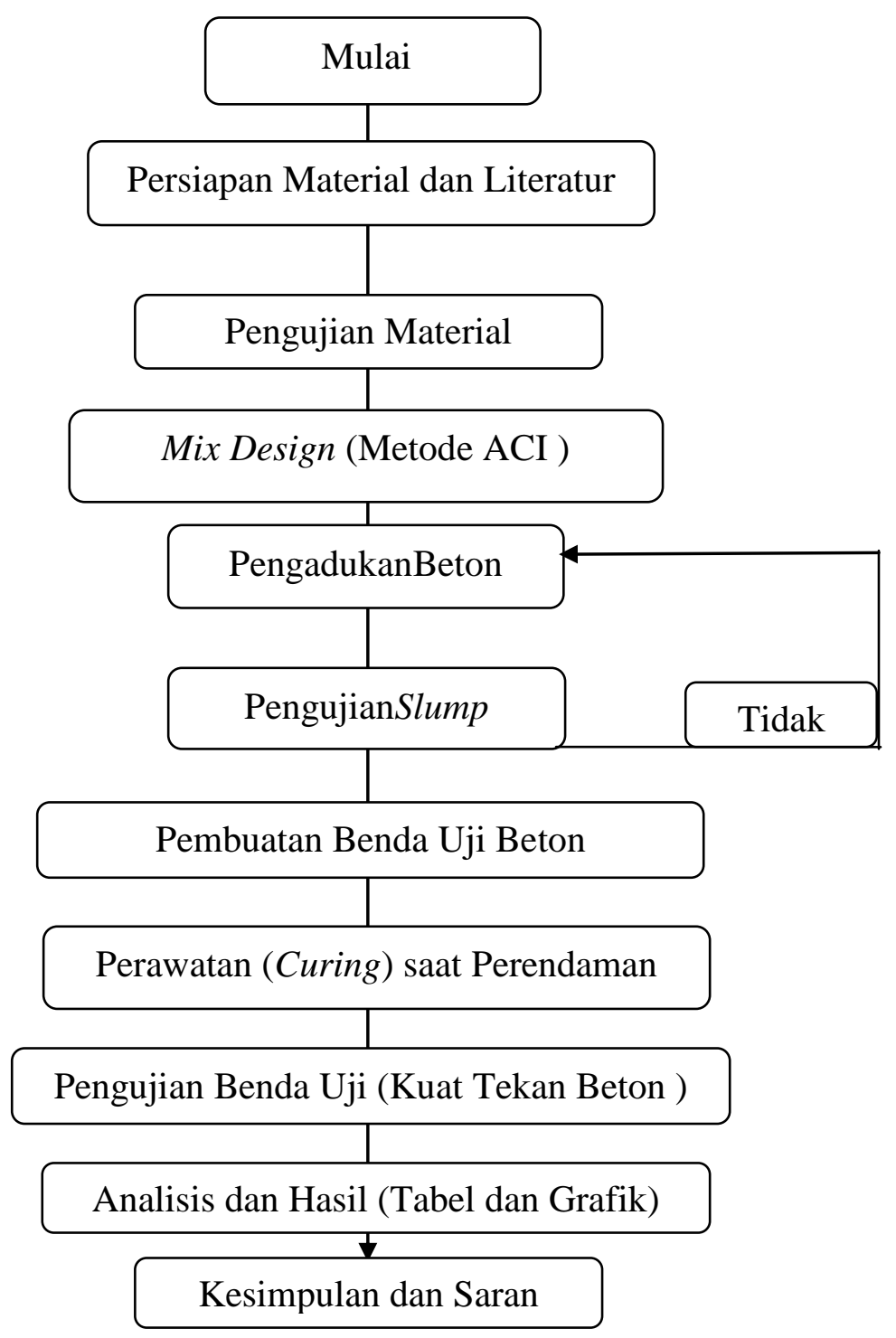

Gambar 3.1. Diagram Alir Pelaksanaan Penelitian

\subsection{Lokasi Penelitian}

Penelitian dan pengamatan dilakukan di Laboratorium Bahan dan Konstruksi Program Studi Teknik Sipil Universitas HKBP Nommensen Medan, Jalan Sutomo No. 4A Medan 20235. 


\subsection{Tahapan Pengujian Material}

Pengujian material dilakukan untuk mendapatkan mix design. Pengujian material bertujuan untuk mengetahui sifat atau karakteristik yang terdapat dalam material tersebut sesuai dengan peraturan.

\subsubsection{Pengujian Kehalusan Semen Portland}

3.5.2 Pemeriksaan Berat Jenis Semen Portland

3.5.3 Pemeriksaan Analisis Saringan Agregat

3.5.4 Pengujian Kadar Air Agregat

\subsubsection{Pemeriksaan Berat Isi Agrega}

3.5.6 Pemeriksaan Berat Jenis dan Penyerapan Agregat Kasar

3.5.7 Pemeriksaan Berat Jenis dan Penyerapan Agregat Halus

3.5.8 Pemeriksaan Kadar Lumpur Agregat Halus

3.5.8 Pemeriksaan Keausan Agregat Kasar dengan Mesin Los Angeles

3.5.9 Pemeriksaan Kehalusan Abu Tongkol Jagung

3.5.10 PemeriksaanKonsistensi Normal dan Pengikatan awal Semen Portland

\subsection{Tata Cara Pembuatan Rencana Mix Design Menurut SNI 03-2834-1993}

Berdasarkan SNI 03-2834-1993, dalam perencanaan campuran beton adalah sebagai berikut :

a. Penetapan kuat tekan beton yang disyaratkan $\left(f^{\prime} c\right)$ pada umur tertentu. Kuat tekan beton yang disyaratkan ditetapkan sesuai dengan persyaratan perencanaan struktur dan kondisi setempat. Untuk struktur bangunan tahan gempa disyaratkan kuat tekan beton lebih dari $20 \mathrm{Mpa}$.

b. Penetapan nilai deviasi standar $(s)$. Deviasi standar ditetapkan berdasarkan tingkat mutu penegendalian dalam pelaksanaan pencampuran beton. Semakin baik tingkat pengendalian mutu, semakin kecil nilai deviasi standarnya. Jika jumlah benda uji minimal 30 buah, maka data standar deviasi yang dimiliki bisa langsung digunakan. Jika jumlah benda uji kurang dari 30 buah, maka harus dilakukan penyesuaian.

c. Menentukan nilai tambah atau margin $(m)$

$$
m=1,34 s \mathrm{Mpa} \quad \text { atau }
$$

Received May 11 ${ }^{\text {th }}$, 2020; Revised June 18 ${ }^{\text {th }}$, 2020; Accepted June $20^{\text {th }}$, 2020 


$$
m=2,33 s-3,5 \mathrm{Mpa}
$$

Tabel 3.2. Nilai Margin jika Data Tidak Tersedia Untuk Menetapkan Deviasi Standar

\begin{tabular}{|c|c|}
\hline $\begin{array}{c}\text { Persyaratan Kuat Tekan, } f^{\prime} c, \\
(\mathrm{Mpa})\end{array}$ & $\begin{array}{c}\text { Margin (m), } \\
(\mathrm{Mpa})\end{array}$ \\
\hline$<21 \mathrm{Mpa}$ & 7,0 \\
\hline $21 \mathrm{~s} / \mathrm{d} \mathrm{35}$ & 8,5 \\
\hline$>35$ & 10,0 \\
\hline
\end{tabular}

d. Menetapkan nilai kuat tekan rata-rata yang harus direncanakan dengan menggunakan rumus : $f^{\prime} c r=f^{\prime} c+m$

e. Menentukan nilai faktor air semen (FAS); untuk tahapan ini bisa dilakukan dengan dua cara yaitu :

f. Cara pertama : berdasarkan kuat tekan rata-rata silinder beton yang direncanakan pada umur tertentu berdasarkan Gambar 3.2

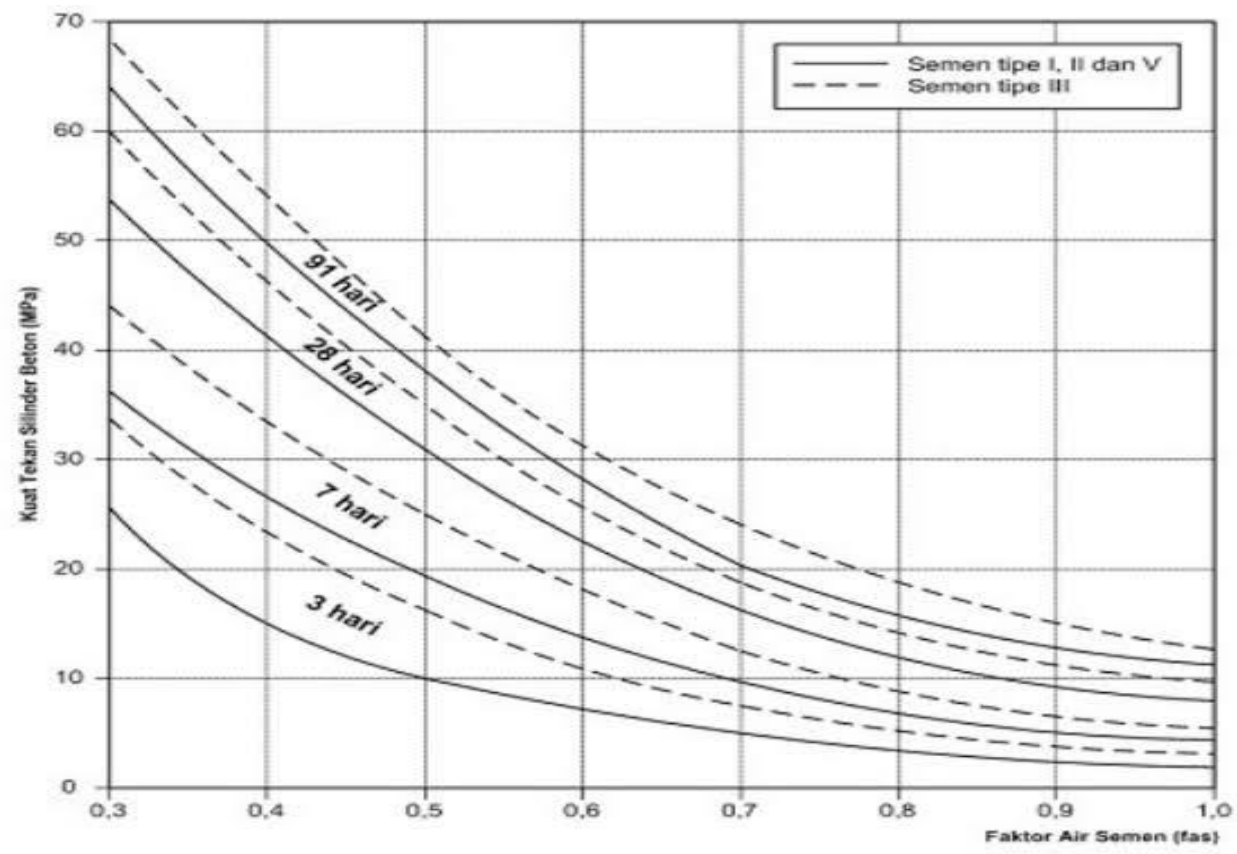

Gambar 3.2.Hubungan Faktor Air Semen dan Kuat Tekan Rata-rata Silinder Beton (sebagai perkiraan nilai FAS dalam rancang campuran)

2. Cara kedua : untuk benda uji kubus, berdasarkan jenis semen yang digunakan, jenis agegat kasar, dan kuat tekan rata-rata beton yang direncanakan pada umur tertentu, 
dapat ditetapkan nilai faktor air semen dari Tabel 3.2. dan Gambar, dengan langkahlangkah sebagai berikut :

a. Perhatikan Tabel 3.2. di bawah ini. Berdasarkan data jenis semen, jenis agregat kasar, dan umur beton rencana, diperkirakan nilai kuat tekan beton yang akan diperoleh, jika

b. dipakai faktor air semen, sebesar 0,50.

Tabel 3.3. Perkiraan Kuat Tekan Beton (Mpa) dengan FAS 0,50

\begin{tabular}{|c|c|c|c|c|c|}
\hline \multirow{2}{*}{$\begin{array}{c}\text { Jenis } \\
\text { Semen }\end{array}$} & \multirow{2}{*}{ Jenis AgregatKasar } & \multicolumn{4}{|c|}{ Umur (hari) } \\
\cline { 3 - 6 } & \multirow{2}{*}{ I,II,V } & 3 & 7 & 28 & 91 \\
\cline { 2 - 6 } & Alami & 17 & 23 & 33 & 40 \\
\hline \multirow{2}{*}{ III } & Batu pecah & 19 & 27 & 37 & 45 \\
\cline { 2 - 6 } & Alami & 21 & 28 & 38 & 44 \\
\hline
\end{tabular}

c. Lihat Gambar. Lukislah titik A pada Gambar dengan nilai FAS 0,50 (sebagai absis) dan kuat tekan beton yang diperoleh dari Tabel 3.2. (sebagai ordinat). Kemudian pada titik A tersebut dibuat grafik baru yang betuknya sama/mengikuti 2 buah grafik yang ada di dekatnya. Selanjutnya tarik garis mendatar dari sumbu tegak di sebelah kiri, sesuai dengan kuat tekan yang direncanakan, sampai memotong grafik baru tersebut, lalu tarik garis ke bawah untuk memperoleh nilai faktor air semen yang sesuai.

d. Menetapkan nilai faktor air semen maksimum. Agar beton yang diperoleh awet dan mampu bertahan terhadap pengaruh lingkungan sekitarnya, perlu ditetapkan nilai FAS maksimum menurut Tabel 3.3. 


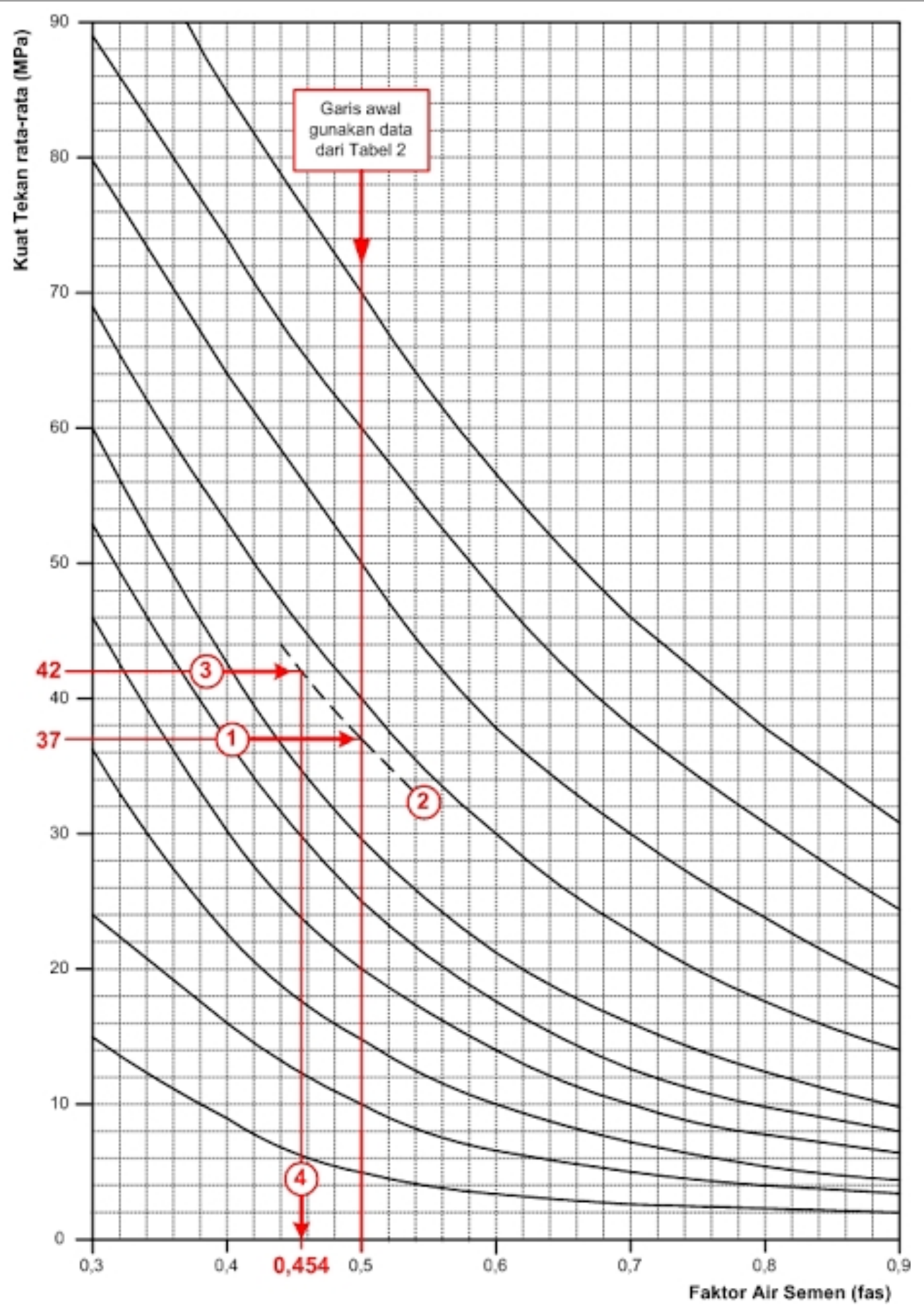

Gambar 3.3.

Hubungan FAS dan Kuat Tekan Rata-rata Silinder

Tabel 3.4. Persyaratan Nilai FAS Maksimum untuk Berbagai Pembetonan di Lingkungan Khusus

Received May 11 ${ }^{\text {th }}$,2020; Revised June 18 ${ }^{\text {th }}$,2020; Accepted June $20^{\text {th }}, 2020$ 


\begin{tabular}{|l|c|c|}
\hline \multicolumn{1}{|c|}{ Jenis Pembetonan } & FAS Maksimum & $\begin{array}{c}\text { Semen Minimum } \\
\left(\mathrm{kg} / \mathrm{m}^{3}\right)\end{array}$ \\
\hline $\begin{array}{l}\text { Beton di dalam ruang bangunan : } \\
\text { a. Keadaan sekeliling non-korosif } \\
\begin{array}{l}\text { b. Keadaan sekeliling korosif akibat } \\
\text { kondensasi atau uap korosi }\end{array}\end{array}$ & 0,60 & 275 \\
\hline $\begin{array}{l}\text { Beton di luar ruang bangunan : } \\
\text { a. Tidak terlindung dari hujan dan terik } \\
\text { matahari langsung }\end{array}$ & 0,52 & 325 \\
$\begin{array}{l}\text { b. Terlindung dari hujan dan terik } \\
\text { matahari langsung }\end{array}$ & 0,60 & 275 \\
\hline $\begin{array}{l}\text { Beton di luar ruang bangunan : } \\
\text { a.Mengalami keadaan basah dan kering } \\
\text { berganti-ganti }\end{array}$ & 0,55 & 325 \\
\hline $\begin{array}{l}\text { b.Mendapat pengaruh sulfat dan alkali } \\
\text { dari tanah }\end{array}$ & \multicolumn{2}{|c|}{ Lihat Tabel 3.5. } \\
\cline { 2 - 3 } $\begin{array}{l}\text { Beton yang selalu berhubungan dengan } \\
\text { air tawar/payau/laut }\end{array}$ & \multicolumn{2}{|c|}{ Tabel 3.4 } \\
\hline
\end{tabular}

Tabel 3.5. Ketentuan Minimum untuk Beton Bertulang Dalam Air

\begin{tabular}{|c|c|c|c|c|c|}
\hline \multirow[t]{3}{*}{ Jenis Beton } & \multirow{3}{*}{$\begin{array}{c}\text { Kondisi } \\
\text { Lingkungan } \\
\text { berhubungan } \\
\text { dengan }\end{array}$} & \multirow{3}{*}{$\begin{array}{l}\text { Faktor air } \\
\text { semen } \\
\text { maksimum }\end{array}$} & \multirow[t]{3}{*}{ Tipe Semen } & \multicolumn{2}{|c|}{$\begin{array}{l}\text { Kandungan Semen } \\
\text { Minimum }\left(\mathrm{kg} / \mathrm{m}^{2}\right)\end{array}$} \\
\hline & & & & \multicolumn{2}{|c|}{ Agregat maks. } \\
\hline & & & & $40 \mathrm{~mm}$ & $20 \mathrm{~mm}$ \\
\hline \multirow{3}{*}{$\begin{array}{l}\text { Bertulang atau } \\
\text { Prategang }\end{array}$} & Air tawar & 0,50 & Semua Tipe I-V & 280 & 300 \\
\hline & Air payau & 0,45 & $\begin{array}{c}\text { Tipe I + Pozolan } \\
(15 \%-40 \%) \text { atau } \\
\text { PPC }\end{array}$ & 340 & 380 \\
\hline & Air laut & 0,50 & Tipe II atau V & 290 & 330 \\
\hline
\end{tabular}


Tabel 3.6. Ketentuan untuk Beton yang Berhubungan dengan Air Tanah yang

\section{Mengandung Sulfat}

\begin{tabular}{|c|c|c|c|c|c|c|c|c|}
\hline \multirow{3}{*}{$\begin{array}{l}\text { Kadar } \\
\text { gangguan } \\
\text { Sulfat }\end{array}$} & \multicolumn{3}{|c|}{ Konsentrasi Sulfat sebagai $\mathrm{SO}_{2}$} & \multirow{3}{*}{$\begin{array}{l}\text { Tipe } \\
\text { Semen }\end{array}$} & \multirow{2}{*}{\multicolumn{3}{|c|}{$\begin{array}{l}\text { Kandungan } \\
\text { semen minimum } \\
\text { berdasarkan } \\
\text { ukuran agregat } \\
\text { maksimum } \\
\left(\mathrm{kg} / \mathrm{m}^{3}\right)\end{array}$}} & \multirow{3}{*}{$\begin{array}{l}\text { Nilai } \\
\text { FAS } \\
\text { Maks }\end{array}$} \\
\hline & \multicolumn{2}{|c|}{ Dalam Tanah } & \multirow[t]{2}{*}{$\begin{array}{l}\text { Sulfat } \\
\left(\mathrm{SO}_{2}\right) \\
\text { dalam } \\
\text { air } \\
\text { tanah } \\
\mathrm{g} / 1\end{array}$} & & & & & \\
\hline & $\begin{array}{c}\text { Total } \\
\mathrm{SO}_{2}(\%)\end{array}$ & $\begin{array}{l}\mathrm{SO}_{2} \\
\text { dalam } \\
\text { campuran } \\
\text { Air : } \\
\text { Tanah = } \\
2: 1 \mathrm{~g} / 1\end{array}$ & & & $\begin{array}{c}40 \\
\mathrm{~mm}\end{array}$ & $\begin{array}{c}20 \\
\mathrm{~mm}\end{array}$ & $\begin{array}{c}10 \\
\mathrm{~mm}\end{array}$ & \\
\hline 1. & $\begin{array}{l}\text { Kurang } \\
\text { dari } 0,2\end{array}$ & $\begin{array}{l}\text { Kurang } \\
\text { dari } 1,0\end{array}$ & $\begin{array}{l}\text { Kurang } \\
\text { dari } 0,3\end{array}$ & $\begin{array}{l}\text { Tipe I } \\
\text { dengan } \\
\text { atau tanpa } \\
\text { pozzolan } \\
(15-40 \%)\end{array}$ & 80 & 300 & 350 & 0,50 \\
\hline \multirow[t]{3}{*}{2.} & \multirow[t]{3}{*}{$0,2-0,5$} & \multirow[t]{3}{*}{$1,0-1,9$} & \multirow[t]{3}{*}{$0,3-1,2$} & Tipe I & 290 & 330 & 350 & 0,50 \\
\hline & & & & $\begin{array}{l}\text { Tipe I } \\
\text { pozzolan } \\
(15-40 \%) \\
\text { atau PPC }\end{array}$ & 270 & 310 & 360 & 0,55 \\
\hline & & & & $\begin{array}{l}\text { Tipe II } \\
\text { atau Tipe } \\
\text { IV }\end{array}$ & 250 & 290 & 340 & 0,55 \\
\hline \multirow[t]{2}{*}{3.} & \multirow[t]{2}{*}{$0,5-1,0$} & \multirow[t]{2}{*}{$1,9-3,1$} & \multirow[t]{2}{*}{$1,2-2,5$} & $\begin{array}{l}\text { Tipe I } \\
\text { pozzolan } \\
(15-40 \%) \\
\text { atau PPC }\end{array}$ & 340 & 380 & 430 & 0,45 \\
\hline & & & & $\begin{array}{l}\text { Tipe II } \\
\text { atau Tipe } \\
\text { V }\end{array}$ & 290 & 330 & 380 & 0,50 \\
\hline 4. & $1,0-2,0$ & $3,1-5,6$ & $2,5-5,0$ & $\begin{array}{l}\text { Tipe II } \\
\text { atau Tipe }\end{array}$ & 330 & 370 & 420 & 0,45 \\
\hline
\end{tabular}

Received May 11 ${ }^{\text {th }}$, 2020; Revised June 18 ${ }^{\text {th }}$, 2020; Accepted June $20^{\text {th }}$, 2020 


\begin{tabular}{|l|l|l|l|l|l|l|l|l|}
\hline & & & & V & & & & \\
\hline 5. & $\begin{array}{l}\text { Lebih dari } \\
2,0\end{array}$ & $\begin{array}{l}\text { Lebih } \\
\text { dari 5,6 }\end{array}$ & $\begin{array}{l}\text { Lebih } \\
\text { dari 5,0 }\end{array}$ & $\begin{array}{l}\text { Tipe II } \\
\text { atau Tipe } \\
\text { V dengan } \\
\text { lapisan } \\
\text { pelindung }\end{array}$ & 330 & 370 & 420 & 0,45 \\
& & & & & & \\
\hline
\end{tabular}

Tabel 3.7. Penetapan Nilai Slump

\begin{tabular}{|l|c|c|}
\hline \multicolumn{1}{|c|}{ Pemakaian Beton } & $\begin{array}{c}\text { Maksimum } \\
(\mathrm{cm})\end{array}$ & $\begin{array}{c}\text { Minimum } \\
(\mathrm{cm})\end{array}$ \\
\hline $\begin{array}{l}\text { Dinding, Pelat Pondasi dan } \\
\text { Pondasi Telapak Bertulang }\end{array}$ & 12,5 & 5,0 \\
\hline $\begin{array}{l}\text { Pondasi Telapak Tidak } \\
\text { Bertulang, Kaison, dan Struktur } \\
\text { di bawah Tanah }\end{array}$ & 9,0 & 2,5 \\
\hline $\begin{array}{l}\text { Pelat, Balok, Kolom, dan } \\
\text { Dinding }\end{array}$ & 15,0 & 7,5 \\
\hline Perkerasan Jalan & 7,5 & 5,0 \\
\hline Pembetonan Masal & 7,5 & 2,5 \\
\hline
\end{tabular}

Tabel 3.8. Perkiraan Kebutuhan Air untuk Setiap Meter Kubik Beton (liter)

\begin{tabular}{|c|l|c|c|c|c|}
\hline \multirow{2}{*}{$\begin{array}{c}\text { Ukuran Agregat } \\
\text { Maksimum } \\
(\mathrm{mm})\end{array}$} & Jenis Batuan & \multicolumn{4}{|c|}{$\begin{array}{c}\text { Slump } \\
(\mathrm{mm})\end{array}$} \\
\cline { 3 - 6 } & & $0-10$ & $10-30$ & $30-60$ & $60-180$ \\
\hline \multirow{2}{*}{20} & Alami & 150 & 180 & 205 & 225 \\
\cline { 2 - 6 } & Batu pecah & 180 & 205 & 230 & 250 \\
\hline \multirow{2}{*}{40} & Alami & 135 & 160 & 180 & 195 \\
\cline { 2 - 6 } & Batu pecah & 170 & 190 & 210 & 225 \\
\hline & Alami & 115 & 140 & 160 & 175 \\
\cline { 2 - 6 } & Batu pecah & 155 & 175 & 190 & 205 \\
\hline
\end{tabular}


Tabel 3.9. Batas Gradasi Agregat Halus Menurut SNI 03-2834-1993

\begin{tabular}{|c|c|c|c|c|}
\hline \multirow{2}{*}{ Ukuran Saringan } & \multicolumn{4}{|c|}{ Persentase Berat yang Lolos Saringan } \\
\cline { 2 - 5 } & $\begin{array}{c}\text { Gradasi Zona } \\
\text { I }\end{array}$ & $\begin{array}{c}\text { Gradasi } \\
\text { Zona II }\end{array}$ & $\begin{array}{c}\text { Gradasi } \\
\text { Zona III }\end{array}$ & $\begin{array}{c}\text { Gradasi } \\
\text { Zona IV }\end{array}$ \\
\hline $9,60 \mathrm{~mm}$ & 100 & 100 & 100 & 100 \\
\hline $4,80 \mathrm{~mm}$ & $90-100$ & $90-100$ & $90-100$ & $95-100$ \\
\hline $2,40 \mathrm{~mm}$ & $60-95$ & $75-100$ & $85-100$ & $95-100$ \\
\hline $1,20 \mathrm{~mm}$ & $30-70$ & $55-90$ & $75-100$ & $90-100$ \\
\hline $0,60 \mathrm{~mm}$ & $15-34$ & $35-59$ & $60-79$ & $80-100$ \\
\hline $0,30 \mathrm{~mm}$ & $5-20$ & $8-30$ & $12-40$ & $15-50$ \\
\hline $0,15 \mathrm{~mm}$ & $0-10$ & $0-10$ & $0-10$ & $0-15$ \\
\hline
\end{tabular}

Tabel 3.10. Perencanaan Mix Design

\begin{tabular}{|c|c|c|}
\hline No. & Uraian & \\
\hline 1. & Kuat tekan yang disyaratkan pada umur 28 hari (f'c) & $25 \mathrm{MPa}$ \\
\hline 2. & Deviasi standar (s) & $7 \mathrm{MPa}$ \\
\hline 3. & Nilai tambah (m) & $1,64 \times 7=11,5 \mathrm{Mpa}$ \\
\hline 4. & Kuat tekan rata-rata yang direncanakan (f'cr) & $25+11,5=36,5 \mathrm{MPa}$ \\
\hline 5. & Jenis semen & Tipe I \\
\hline \multirow[t]{2}{*}{6.} & \multirow{2}{*}{$\begin{array}{r}\text { Jenis agregat : - agregat kasar } \\
\text { - agregat halus }\end{array}$} & Batu pecah \\
\hline & & Alami \\
\hline \multirow[t]{3}{*}{7.} & \multirow{3}{*}{$\begin{aligned} \text { Faktor Air Semen : - cara } 1 \\
\\
\text { - cara } 2 \\
\text { - FAS Maks. }\end{aligned}$} & 0,43 (Grafik) \\
\hline & & 0,52 (Tabel) \\
\hline & & 0,6 (Syarat) \\
\hline 8. & Faktror Air Semen yang dipakai & 0,43 \\
\hline 9. & Slump & $30-60 \mathrm{~mm}$ \\
\hline 10. & Ukuran Agregat Maksimum & $40 \mathrm{~mm}$ \\
\hline 11. & Kadar Air Bebas & $170 \mathrm{~kg} / \mathrm{m}^{3}$ (Tabel) \\
\hline 12. & Jumlah semen & $395,35 \mathrm{~kg} / \mathrm{m}^{3}$ \\
\hline 13. & Jumlah semen maks. & - \\
\hline 14. & Jumlah semen minimum & $275 \mathrm{~kg} / \mathrm{m}^{3}$ \\
\hline 15 . & Jumlah semen yang dipakai & $395,35 \mathrm{~kg} / \mathrm{m}^{3}$ \\
\hline 16. & Faktor Air Semen yang disesuaikan & 0,43 \\
\hline 17. & Susunan butiran agregat halus & Daerah Gradasi 2 \\
\hline
\end{tabular}




\begin{tabular}{|c|c|c|}
\hline \multirow[t]{2}{*}{18.} & \multirow{2}{*}{$\begin{array}{l}\text { Berat Jenis Agregat Halus } \\
\text { Berat Jenis Agregat Kasar }\end{array}$} & $2,2 \mathrm{gr} / \mathrm{cm}^{3}$ \\
\hline & & $2 \mathrm{gr} / \mathrm{cm}^{3}$ \\
\hline 19. & Persen agregat halus & $35 \%$ \\
\hline 20. & Berat Jenis SSD & $2,1 \mathrm{gr} / \mathrm{cm}^{3}$ \\
\hline 21. & Berat Isi Beton & $2380 \mathrm{~kg} / \mathrm{m}^{3}$ \\
\hline 22. & Kadar Air Gabungan & $1814,65 \mathrm{~kg} / \mathrm{m}^{3}$ \\
\hline 23. & Kadar Agregat Kasar & $635,12 \mathrm{~kg} / \mathrm{m}^{3}$ \\
\hline 24. & Kadar Agregat Halus & $1179,53 \mathrm{~kg} / \mathrm{m}^{3}$ \\
\hline
\end{tabular}

Proporsi campuran

\begin{tabular}{|c|c|c|c|c|c|}
\hline \multirow{2}{*}{ Jumlah bahan (teoritis) } & \multirow{2}{*}{ Semen } & \multirow{2}{*}{ Air } & \multicolumn{2}{|c|}{ Agregat Kering SSD } & \multirow{2}{*}{ Beratisi } \\
\hline & & & Halus & Kasar & \\
\hline Tiap $\mathrm{m}^{3}$ & 395,35 & 170 & 635,12 & 1179,53 & 2380 \\
\hline Tiap benda uji $0,12 \mathrm{~m}^{3}$ & 47,442 & 20,4 & 76,214 & 141,54 & 285,596 \\
\hline
\end{tabular}

Proporsi campuran koreksi

\begin{tabular}{|c|c|c|c|c|c|}
\hline \multirow{2}{*}{ Jumlah bahan } & \multirow{2}{*}{ Semen } & \multirow{2}{*}{ Air } & \multicolumn{2}{|c|}{ Agregat Kering SSD } & \multirow{2}{*}{ Beratisi } \\
\cline { 4 - 5 } & & & Halus & Kasar & \\
\hline Tiap m & & & & & \multirow{2}{*}{2380,1706} \\
& \multirow{2}{*}{395,53} & 206,293 & 622,4176 & 1155,93 & \\
\hline Tiap benda uji $0,12 \mathrm{~m}^{3}$ & 47,442 & 24,755 & 74,69 & 1387,116 & 1534,003 \\
\hline
\end{tabular}

\section{ANALISIS DAN HASIL}

\subsection{Hasil Pengujian Karakteristik Agregat}

4.1.1 Hasil Pengujian Agregat Halus dan Agregat kasar

4.1.2 Hasil PengujianKehalusan Semen dan Abu Tongkol Jagung

\subsection{Hasil PengujianKuat Tekan Beton (MPa)}

- Komposisi abu tongkol jagung 0\%

- Komposisi abu tongkol jagung 3\%

- Komposisi abu tongkol jagung 6\% 
- Komposisi abu tongkol jagung $9 \%$

\section{KESIMPULAN DAN SARAN}

1. Peningkatan suhu evaporator (heat source) akan mempengaruhi efektifitas perpindahan panas dan hambatan termal pada APKLT

2. Efektifitas perpindahan panas pada APKLT yang berfluida kerja R134a menurun seiring peningkatan kecepatan aliran udara pada saluran $(d u c t)$.

3. Tekanan fluida kerja berpengaruh terhadap efektifitas perpindahan panas pada APKLT. Semakin tinggi tekanan R134a maka efektifitas semakin meningkat. Efektivitas perpindahan panas APKLT fluida kerja bertekanan 1,2 MPa sekitar 30-68\% dan lebih tinggi dibandingkan efektivitas perpindahan panas APKLT fluida kerja bertekanan 0,8 MPa sekitar 22-35\%. Hambatan termal APKLT bertekanan 0,8 $\mathrm{MPa}$ sekitar $0,3-0,45^{\circ} \mathrm{C} / \mathrm{W}$ dan lebih besar dari hambatan termal APKLT bertekanan 1,2 MPa sekitar 0,08-0,4 ${ }^{\circ} \mathrm{C} / \mathrm{W}$.

\section{DAFTAR PUSTAKA}

Antoni \& Paul Nugraha, 2007, Teknologi Beton, Penerbit C.V Andi Offset, Yogyakarta.

Dipohusodo, Istimawan1993,Sturktur Beton Bertulang berdasarkan SK SNI T-15-199103, Departemen Pekerjaan Umum, Jakarta.

Fakhrunisa, N, Boedya, D, Adjib, K 2018, 'Kajian Penambahan Abu BonggolJagung Yang Bervariasi Dan BahanTambah Superplasticizer Terhadap Sifat Fisik Dan MekanikBetonMemadatSendiri (Self-Compacting Concrete)', JurnalBangunan, Vol.23, No.2.

Hadi, M 2018, 'Mengenal Beton Hijau Green Concerete', ilmubeton.com, 11 Mei 2020,(https://www.ilmubeton.com/2018/07/mengenal-beton-hijau-greenconcrete.html).

Hepiyanto, R \& Mohammad, A F 2019,'Pengaruh Penambahan Abu Bonggol JagungTerhadap Kuat Tekan Beton K-200', Universitas Islam Lamongan, Lamongan.

Juwanto, Ratih, F, Turyanto, Andriani, A, Prasetyo, O, Supyono2017,'Pemanfaatan Bahan Additive Abu Batang Jagung dan Bonggol Jagung Sebagai Bahan Tambahan Pembuatan Beton Ringan Ramah Lingkungan', Universitas Semarang, Semarang.

Mulyono, Tri2005,Teknologi Beton, Penerbit C.V Andi Offset, Yogyakarta. 
Pendidikan, D 2014, Tanaman Jagung - Syarat Tumbuh, Ciri, Teknik, Analisis Usaha, dosenpendidikan.co.id, 25 September 2019, ( https://www.dosen pendidikan.co.id / tanaman-jagung).

'Peraturan Beton Bertulang Indonesia 1971' 2018, mycivilian.files.wordpress.com, 30 September 2019, (https://mycivilian.files.wordpress.com/2018/01/pbi-1971peraturan-beton-bertulang-indonesia.pdf).

Tjokrodimulyo, K 2007, Tekonologi Beton, Biro Penerbit KMTS FT UGM, Yogyakarta.

Wahyudi, L \& Syahril, A R 1997, Struktur Beton Bertulang, PT Gramedia Utama, Jakarta. 